\title{
Rationales and Instruments for Public Innovation Policies
}

\author{
Tuomas Takalo*
}

\begin{abstract}
Bank of Finland, Monetary Policy and Research Department, P.O. BOX 160, Fl-00101 Helsinki, Finland
Abstract: Economic interest in innovation policy largely arises from the fundamental importance of innovation to social welfare and from inefficiencies in innovation in a competitive market environment. As a result, a wide variety of public innovation policies are used in practice. This study reviews the economic justifications for public innovation policies and compares the existing policy tools, paying particular attention to the Finnish innovation policy environment.
\end{abstract}

Keywords: Innovation policies, innovation, R\&D, incentives, market failures.

\section{INTRODUCTION}

At least since the works of Solow $(1956 ; 1957)$ and Arrow (1962) it has been widely acknowledged that innovation is the principal engine of economic growth but that it is fraught market failures (inefficiencies) ${ }^{1}$. As a result, private sector is likely to invest too little in research and development (R\&D) activities. To stimulate private $R \& D$ investments, governments around the world are strengthening the protection of intellectual property, and spending public funds in direct R\&D subsidies and tax incentives. For example, all member countries of Organisation for Economic Cooperation and Development (OECD) use direct R\&D subsidies, and increasingly many offer some form of R\&D tax incentive (Warda 2006; OECD 2011; Busom, Corchuelo and Martinez Ros 2012). They are also increasingly employed in emerging countries, e.g., India uses both of these fiscal policy instruments. Some innovation policy instruments that have been long neglected such as prizes and contests are attracting renewed interest. The goal of this study is to review the economic justifications for innovation policies and available policy tools, especially to the extent they reflect the Finnish institutional environment.

Social and business sciences have proposed a numerous rationales for public innovation policies (see, e.g., Georghiou et al. 2003 and Chaminade and Edquist 2006 for reviews). The starting point is typically

*Address corresponding to this author at the Bank of Finland, Monetary Policy and Research Department, P.O. BOX 160, FI-00101 Helsinki, Finland; Tel: +358108312370; Fax: +358102294; E-mail: tuomas.takalo@gmail.com

${ }^{1}$ The review uses the standard economics terminology which has little to do with so called neoclassical economics. For example, the term market failure refers to any (allocative or productive) inefficiency in the market outcome that is not due to governmental regulation. It hence encompasses the classic failure of competitive markets to obtain socially optimal outcome but also inefficiencies due to imperfect competition, imperfect information and other systemic problems that are not automatically solved by market forces. that innovation in unregulated market environment is inefficient, creating a prima facie case for government intervention. However, potential failure of government policies is also often acknowledged. Any public innovation policy tool should only be judged on whether it yields a net increase in social welfare.

Economic theory has indentified two broad sources of market failures: financial market imperfections and externalities. The review argues that innovation policies aimed at correcting financial market imperfections do not necessarily pass the criterion of net welfare gain in normal times outside crisis periods and that externalities provide a much more sound rationale for an innovation policy. The problem with the externality rationale is the opposite - it is too general to successfully provide detailed innovation policy advice and the welfare benefits of policies must be evaluated case by case.

The report then reviews the major innovation policy tools used in practice: intellectual property, subsidies, tax incentives, prizes and contests, and public production and procurement. The policy tools can be classified according to their ability to provide incentives to innovate ex ante and diffusing innovations ex post. Intellectual property also differs from other instruments in the sense that has smaller direct fiscal consequences. It turns out that intellectual property and tax reliefs are in theory better in mitigating the ex ante problem than the other policy tools, but fare worse in solving the ex post problem. However, some theoretical advantages of the other policy tools in solving the ex post problem are wiped out by the way they are used in practice.

Finnish innovation policy system is currently based on a subset of main tools: intellectual property, subsidies and public production. For example, tax reliefs and prizes are used in a very restrictive manner but, following the trend in the OECD countries, a more 
extensive use of tax reliefs is planned by the current Government. It appears that the tools are used simultaneously and uncoordinatedly (like in many other countries), resulting in outcomes that are sometimes at odds with the standard predictions of economic theory.

The next section summarizes the economic justifications for innovation policies, and Section 3 compares the available policy tools. Section 4 reviews the Finnish practices and Section 5 concludes.

\section{RATIONALES FOR PUBLIC INNOVATION POLICIES}

Several rationales for the innovation policy have been proposed by policy makers and academics. Economics textbooks begin with the benchmark of a competitive market without public innovation policies. It is then observed that the rate of innovation in the competitive market is generally inefficient, justifying an innovation policy aimed at improving the market outcome. While this textbook benchmark is clearly unrealistic (e.g., the markets are virtually never competitive and unregulated), the reasons that render innovation in competitive markets inefficient also render innovation in more realistic environment inefficient. Hence these reasons - so called market failures - form a necessary condition for public innovation policies. However, the market failures do not form a sufficient condition for government intervention. In particular, it is possible that government innovation policies - even if they are benevolent - have unintended consequences, worsening the market outcome ${ }^{2}$.

The economic science has indentified two broad sources of market failures, financial market imperfections and externalities.

\subsection{Financial Market Imperfections}

It is a widely held view that corporate R\&D is held back by insufficient private sector external funding, necessitating public innovation finance policies. On the face of it, the argument sounds unobjectionable. R\&D activities are inherently opaque, human capital intensive, and involve soft information. It is hard for outside investors to assess the creditworthiness of $R \& D$ projects and verify their returns. Hence the markets for innovation finance are plagued by

${ }^{2}$ Furthermore, recent research (e.g., Boldrin and Levine 2008; Henry and Ponce 2011) has challenged the conventional wisdom suggesting that the competitive pace of innovation is not necessarily suboptimal. problems of adverse selection and moral hazard stemming from informational asymmetries between insiders and outsiders ${ }^{3}$. Such problems of asymmetric information are known to hamper efficient allocation of finance. For example, the celebrated contribution by Stiglitz and Weiss (1981) suggests that adverse selection leads to insufficient lending to entrepreneurs, and even to the collapse of the market for entrepreneurial finance. Moreover, the standard market solutions provided to adverse selection and moral hazard - signaling, reputation and monitoring by financial intermediaries - may fail especially in the case of science and technology-based new firms that have neither acquired reputation nor assets that could be offered as collateral.

That financial market imperfections create inefficiencies in innovation finance clearly constitutes a necessary condition for government intervention. However, it is neither clear that they would also constitute a sufficient condition nor that they would call for public R\&D funding. Indeed, there is sound theoretical argument, first advanced by de Meza and Webb (1987) that, in the absence of externalities, adverse selection leads to overlending to $R \& D$ activities. Since outside financiers cannot separate good projects from bad ones, they typically end up with financing both kinds of projects. Thus good projects will cross-subsidize bad ones and too much bad projects will be funded. The overinvestment problem worsens when funding becomes cheap to come by (e.g., when financial markets are competitive and liquid). Hence in this kind of environment the proper government intervention arising from financial market imperfections is that external funding of R\&D investments or their returns should be taxed, not subsidized.

Moreover, the private sector has created sophisticated organizations and instruments to overcome the problem of adverse selection and if such private sector mechanism fail, it is difficult to see why public funding agencies would be able to perform better.

Literature syntheses such as de Meza (2002) and Boadway and Keen (2006) showed that it is difficult to come up with a theoretically coherent argument for public innovation finance arising from adverse

\footnotetext{
${ }^{3}$ Adverse selection refers to situations where entrepreneurs have better information about expected project returns than financiers at the time of writing a financing contract, and moral hazard to situations where actions taken by entrepreneurs cannot be verified to third parties (e.g., to courts).
} 
selection. Researches have had to resort to quite creative arguments to rescue the adverse selection rationale for public innovation support policies. It has been proposed that to the extent public innovation finance institutions are centralized and engage in screening activities, they are in a better position to aggregate information about $R \& D$ innovation projects than dispersed private sector financiers (Niinimäki and Takalo 2007). Moreover, the public sector screening activities can have a certification role: even low quality screening by a public agency may provide an informative signal to private sector financiers, hence mitigating the adverse selection problem - although this could dilute the private sector financiers' incentives to screen (Lerner 2002 and Takalo and Tanayama 2010).

A sounder rationale for public innovation finance comes from moral hazard. Holmström and Tirole (1997) showed that outsider investors are wary of investing in the projects of the entrepreneurs who cannot put down a sufficient amount of their own capital. If the entrepreneurs do not keep a sufficient stake in the project outcomes, the financiers cannot be sure about the entrepreneurs' motivation. This creates a funding gap where even unambiguously profitable projects are not launched if the entrepreneurs do not have enough liquid assets. Especially human capital intensive start-ups may lack assets and therefore suffer from funding gap. Monitoring by banks or specialized innovation-finance organizations such venture capitalists helps to mitigate the moral hazard problem, but may or may not be sufficient to eliminate it. In line with these arguments, Takalo, Tanayama, and Toivanen (2012) showed that costlier external private sector finance of $R \& D$ increases (reduces) the optimal amount public funding for firms encountering (not encountering) binding financial constraints

Empirical evidence about whether investments in $R \& D$ are held back by insufficient finance is broadly speaking consistent with theory. Hall (2002) and Hyytinen and Pajarinen (2003) suggested that only small, R\&D intensive start ups may face financial constraints in industrialized countries with well developed financial markets outside crisis periods. Empirical researchers, however, encounter the same informational problems than outside financiers: it is hard to separate good projects from bad ones. Hence the observation that some firms suffer from funding difficulties may be meaningless, merely indicating that market is doing its job and trying to wipe out bad projects. It is also easy to come up with examples such as the United States (U.S.) subrime mortgage market in the last decade, which show that even massive overlending to risky activities is not implausible.

In sum, economic theory and the scant empirical evidence do not offer unambiguous support for public innovation finance policies that are motivated by financial market imperfections. Only policies that are targeted at solving moral hazard problems or those that involve project screening have some justifications. There could also be a case for counter-cyclical funding policies which increase public innovation finance when liquidity in financial markets dries up and, similarly, reduce it when liquidity is abundant. Otherwise, using financial market imperfections as a rationale for $R \& D$ support policies is challenging.

\subsection{Externalities}

Externalities arise when a firm investing in $R \& D$ does not or cannot take fully into account the effects of its R\&D investments beyond its profits. There are various forms of externalities. R\&D knowledge may spill over to other firms, e.g., via departure of personnel. Such (technological) spillovers play a crucial role in modern growth theory (see, e.g., Aghion and Howitt 2009). Another important externality is consumer surplus. When the output of R\&D is sold in the market, the vendor cannot fully capture the value of its innovation to all users. The technology vendor can seldom perfectly discriminate among its customers so that it could charge a higher price from the customers who value its innovation more. Since some new digital technologies can also easily be copied, some users of the technology pay little or nothing to the vendor. In network industries where the value of an innovation depends on the number of its users, consumer surplus also includes network benefits (or network externalities).

A related externality comes from cumulative innovation (Green and Scotchmer 1995) An innovation of a firm may enable another firms to build on the firm's innovation to make further innovations. Consider for example basic general purpose technologies. They have little value in itself but they facilitate firms to develop innovations with commercial applications. An original innovator may not necessarily even foresee how its innovation is used in the future. Since the chain of cumulative innovations may be in the case of pioneering, path breaking innovations be enormous (think, e.g., world wide web), the original innovator may capture only a small fraction of the social value of her innovation. 
Note that externalities can also be negative from the welfare point of view. It may for example turn out that some new technologies cause such a large environmental damage that the social value of the new technology is negative. At least theoretically important negative externalities in the case of $R \& D$ arise from business stealing and the duplication of $R \& D$ costs. For example, a firm investing in a developing new drug and obtaining a patent for it does not take into account that its investments reduce the probability of other firms to come up with the same drug patent.

Both theoretical and empirical economics literature agrees that the growth enhancing effects of R\&D largely arise from its positive externalities outweighing the negative ones. Externalities, however, by definition hamper the functioning of market mechanism, creating a wedge between social and private value of innovations. If the firm cannot fully appropriate the social return of its investments, it will invest too little and hence public support might be warranted.

R\&D activities generate particularly large externalities because new knowledge, technologies, and creative works have properties of public goods. They do not wear out in use and it may be both hard and socially wasteful to exclude others from using them once they exist. However, new knowledge, technologies and creative works can be very expensive to produce in the first place, and firms are not willing to invest in innovative activities if they know that once they are successful their rivals and consumers can use their innovations without paying an adequate compensation ${ }^{4}$. From the public policy point of view, this gives a rise to the tradeoff between the provision of adequate incentives to innovate ex ante and the smooth diffusion of existing innovations ex post. As will be discussed next section, the various innovation policies can be classified according to their ability to overcome the ex ante problem of providing incentives and the ex post problem of promoting the use of innovations.

The problem with externality rationale is that it is rather broad and cannot easily provide a clear-cut policy advice. Almost all R\&D activities create externalities and almost all R\&D investments might then warrant public support. Note that even commercially failed projects can generate externalities.

\footnotetext{
${ }^{4}$ This argument is challenged by Boldrin and Levine (2008) and Henry and Ponce (2011) who showed that innovators are able to reap sufficient rewards for their investments even without government intervention.
}

Even if financial markets imperfections would justify taxation of R\&D investments as the proper policy intervention, externalities can reverse the policy conclusion and justify R\&D subsidies. In theory the amount of public support to a given $R \& D$ project should be tied to the amount of externalities generated by it. But it is difficult to estimate the level of externalities generated by a given $R \& D$ activity (for an advance to this direction, see Takalo, Toivanen, and Tanayama 2011). If this cannot be done, the externality rationale neither pins down the amount of public support nor what kind of instruments should be used.

\section{PUBLIC INNOVATION POLICIES}

Over the past millenia, rulers and governments have come up with numerous policy tools to support innovation. Using a broad classification, the main policy tools are intellectual property, $R \& D$ subsidies and other public $R \& D$ funding, tax incentives, prizes and contests, and public procurement and production including innovation services. We first briefly review each policy tool, focusing on their most basic economic dimensions, and then compare them against each others. For brevity, the review is restricted to direct innovation policies, ignoring related policies with major implications for innovation such as competition policy and financial market regulation.

\subsection{Intellectual Property}

Intellectual property is probably the most ubiquitous innovation policy tool of modern societies ${ }^{5}$. Over the past 30 there has been a clear global trend to strengthen the legal protection of intellectual property. For an emerging economy, strengthening legal protection of intellectual property may be optimal when the country's own innovation capacity has been developed sufficiently but not necessarily otherwise. Yet, emerging market countries have been introducing stronger protection because a membership in the World Trade Organization involves the signing of the Agreement on the Trade-Related Aspects of Intellectual Property Rights. This agreement establishes a minimum level of protection each member country must provide

\footnotetext{
${ }^{5}$ The term intellectual property is used generically, covering patents and other industrial rights such as utility models and protection of topographies of semiconductor products, as well as copyrights and related rights such as database rights. Economically, if not legally, trade secrets are also an important form of intellectual property. In contrast, the discussion does not apply to trademarks, which differ in their economic function and purpose as pointed out by Menell and Scotchmer (2007).
} 
Intellectual property attempts to solve the externality problem by legal means, allowing exclusive use of the protected knowledge. It has many facets that have been extensively analyzed in the literature (see, e.g., Menell and Scotchmer 2007, for a survey). A unique virtue of intellectual property is that it is a non-fiscal policy tool and, as a result, every invention funded with intellectual property creates a Pareto improvement. In other words, only the users of an innovation pay its R\&D costs, and no other party is taxed to subsidize the development of the innovation. Decentralization of decision making constitutes another great benefit of intellectual property. Finding ideas for invention are left up to the firms and innovators themselves, not to civil servants. Although the innovators do not pay attention to the social value of innovations, the private value of an innovation derived from intellectual property typically correlates with its social value, and hence the R\&D effort is directed to socially valuable projects.

The basic disadvantage of the intellectual property is the dead-weight loss $^{6}$. The economic point of intellectual property is to allow the property right holder to try to exclude others from using the innovation without permission. This almost by definition hampers the use and diffusion of innovations.

Another major drawback of intellectual property is that the boundaries of intellectual property rights are inherently imprecise and are ultimately defined by courts. This not only creates legal and administrative costs but also uncertainty in business environment and scope for opportunistic behavior. Such social costs arising from imprecise boundaries of intellectual property rights are rising and may overweight the benefits of intellectual property system (Bessen and Meurer 2008).

The observation that intellectual property should provide ex ante incentives to innovate but restrict the use of innovations ex post has led to the quest of a proper balance of the scope of intellectual property rights, as if there were an inverse-U shaped relationship between social welfare and the strength of intellectual property protection. For example, when being the Chairman of the Federal Reserve Alan Greenspan frequently (e.g., April 3, 2003 and February $27,2004)$ pondered the question 'If our objective is to

\footnotetext{
${ }^{6}$ When the market price of an innovation is above its marginal production costs, there are potential users who would be willing to purchase the innovation for a price that is higher than marginal cost but below the market price. That such consumers are rationed out constitutes a deadweight loss in economics jargon.
}

maximize economic growth, are we striking the right balance in our protection of intellectual property rights?' While this is not an easy question to answer, it seems that, as an innovation policy tool, intellectual property might be useful in solving the ex ante problem of providing incentives to innovate, but it performs much worse in solving the ex post problem of efficient diffusion of existing innovations.

\subsection{R\&D Subsidies}

R\&D subsides typically given as direct grants (including equity investments) or subsidized loans (including guarantees), whose economic effects are qualitatively similar. They are one of the largest and fastest growing forms of industrial aid in the OECD countries. The extensive empirical literature on $R \& D$ subsidies (see David, Hall and Toole 2000, Klette, Møen, and Griliches 2000, Garciá-Quevedo 2004, Cerulli 2010, and Zúñica-Vicente et al. 2012 for literature reviews) has focused on the question of whether subsidies encourage firms to invest more (so called "additionality") or in a different way (so called "behavioral additionality") in R\&D activities than they would do otherwise. However, it would be more desirable to study the question of whether R\&D subsidies increase social welfare or not, as argued by Takalo et al. (2012).

In an ideal world where governments were omnipotent and benevolent, subsidies constituted an efficient innovation policy tool, since they would be allocated to the projects yielding the highest social rate of return on subsidies. In a less idea world, subsidies should be granted only to the projects where the social rate of return exceeds the opportunity costs of public funds, including the distortionary effects of taxation.

Subsidy policies often involve screening of $R \& D$ projects. While such screening is costly to both the applicants and the government, it in return reveals information to policy makers who can then tailor the subsidies according to the policy objectives, e.g., the projects' potential to create externalities. Since screening activities exhibit large scale economies, information gathering can be more efficient when the allocation of subsidies is centralized.

In theory subsidies would not only be an efficient tool to solve the ex ante problem of providing correct incentives to invest in $R \& D$ but also the ex post problem of use of existing innovations. The subsidy policies could be designed so that they maximize 
externalities and diffusion, e.g., by prioritizing projects where intellectual property is waived, put in the public domain or is weak (e.g. projects committed to open source licensing), or projects which are based on collaborative research.

The weakness of subsidy policies is that their effectiveness heavily hinge on the selection of projects into the subsidy program. There is an element of decentralization, since it is still up to firms to propose the subsidized projects, but it is not evident whether the firms have incentives to propose the right kind of projects. In principle the public agency running the subsidy program should leave the evaluation of commercial potential of proposed projects to the market and concentrate merely on the evaluation of the social benefits of the projects. In this task public servants could have a comparative advantage, but it is not clear whether this is the case in practice.

Being discretionary and monetary, subsidies are also particularly vulnerable to misappropriation both by recipients and public servants. There are no guarantees that the public agency grants subsidies to socially beneficial $R \& D$ and the firms use them accordingly. To mitigate moral hazard temptations, subsidy policies are typically accompanied by extensive safeguards against misappropriation. But such safe-guards are costly and reduce the social rate of return of subsidies.

\subsection{Tax Incentives}

Tax credits are increasingly popular form of public $R \& D$ support in industrialized countries (see Hall and van Reenen 2000, Parsons and Phillips 2007 and Mohnen and Lokshin 2010 for surveys of the empirical literature of R\&D tax credits). For example, OECD (2011) reports that 26 OECD countries use R\&D tax credits, up from 12 in 1995. The goal of tax credits is to reduce the marginal cost of R\&D so the firms are likely to invest more than they would do without tax credits. There is less room of behavioral additionality of encouraging particularly socially valuable projects than in the case of direct subsidies, since firms decide what projects to undertake themselves and the tax credit percent typically does not vary over projects. Nonetheless, this full decentralization of decision making is a virtue which tax credits share with intellectual property. Since the private and social values of $R \& D$ projects are typically correlated, giving incentives to invest more should be a step to the right direction. Correctly designed tax credit schemes might hence be fairly effective in providing ex ante incentives. But using tax incentives to encourage diffusion of $R \& D$ results ex post is challenging.

There is an argument that tax credits would be administratively cheaper and more predictable than, say, direct R\&D grants (see, e.g., Møen 2007). While the argument has its merits, it should be kept in mind that tax credits are also vulnerable to misuse by the firms and protections against this, e.g., special auditing and accounting schemes, are costly and, as pointed out by Georghiou et al. (2003), that tax schemes tend to become complex and are also subject to change.

\subsection{Prizes and Contests}

Prizes are an old way of supporting innovation (see Scotchmer 2004b for a review of theory and practice of the use of prizes). Targeted prizes are posted ex ante by a sponsor (e.g., a public agency) who has identified a problem to be solved. If the rewarded solution is put in the public domain so that everybody can use it freely, the prizes completely solve the ex post problem of diffusion of innovations. The disadvantage of prizes lies with the ex ante problem. Since the public agency awarding targeted prizes does not elicit information from innovators, the public agency should know ex ante what should be invented. The better an unsolved need can be identified and specified in advance, the better targeted prizes work. For example, Clay Mathematics Institute announced in 2000 a $\$ 1.000 .000$ prize for the first solution for each of seven mathematical problems. But, as the famous example of the longitude prize shows, even when the need is clearly specified and known ex ante, it is vulnerable to ex post opportunism by the sponsor (see Sobel 1995 for an entertaining description of the pursuit for the longitude prize). For example, it is not necessarily trivial to determine when the posted problem solved in an adequate manner. And once the problem is solved, why should the sponsoring pubic agency give the reward?

Setting up contests for targeted prizes helps to aggregate information from innovators, as then the sponsor can compare the proposals. But the public agency should still identify ex ante the need to be solved. Recently, the diffusion of internet has enabled both public and private sector to set up innovation prize platforms (such as Challenge.gov and The Innovation Challenge) where not only solutions but also problems are posted. Such crowdsourcing provides a new avenue to identify the right problems for prizes and set 
up contests. Nonetheless, contests inherently involve duplication of R\&D costs when the participants race against each other to obtain the prize.

Another tricky task with prizes is to make sure that they reflect the social value of innovations so that they are of proper size. Over the centuries clever ways to tailor the prizes to the value of innovations have been used. But estimating a proper size for a prize is difficult since this not only depends on the social value of an innovation but also the costs of creating it.

Some of the weaknesses of targeted prizes can be overcome by awarding so called blue-sky prizes. Such prizes are not awarded for innovations that are identified in advance but rather ex post for innovations that the sponsor considers particularly valuable. A bluesky prize could be granted in an ad hoc manner each time the sponsor observes a particularly valuable innovation, but this makes them also particularly exposed to opportunism: why should the sponsor ever grant the prize? Thus, the agencies awarding blue-sky prizes today typically commit to grant the prize, e.g. to the best innovation in a technology class annually. The Nobel Prize is probably the most well-known example of blue-sky prizes.

\subsection{Public Procurement and Production}

Governments can also provide services to complement private sector innovation, directly produce innovations themselves, or buy innovations from private contractors. Such public procurement and production of innovations and complementary services have been widely used thorough the economic history (see, e.g., Scotchmer 2004b). Public sector today produces a number of innovations in public universities and research laboratories, and is engaged in partnerships with equivalent private entities. It also provides advice, tools and other services to private sector innovators. Armed forces and public hospitals are major sources of innovation procurement.

In theory, some public innovation support services, direct public production and procurement share the benefits and costs with targeted prizes. On the one hand, the ex ante incentives to innovate are inefficient, since the decision of what to invent and of what information is produced is made by the government. But on the other hand, nothing prevents efficient diffusion of innovations ex post. Indeed, traditionally one major goal of public universities has been to diffuse information freely and some public innovation support services share this goal. However, a part of public procurement and production is concentrated on nationally strategic sectors with the purpose of minimizing the diffusion of research results.

Some public innovation support services such as advice broadly speaking share the benefits and costs of subsidies, putting a burden on the public servants' abilities and leaving the ultimate decision of what to invent to the private sector.

\subsection{Discussion}

As Sections 3.1-3.5 suggest, all innovation policies encounter the tradeoff of encouraging investments in innovative activities ex ante and promoting the use of innovations ex post. Some instruments such as intellectual property and tax reliefs are better in solving the ex ante problem and some instruments such as prizes better in solving the ex post problem. Fiscal implications of intellectual property also differ from other tools since innovations financed by intellectual property on the one hand require little public funding but on the other hand they heavily burden the law enforcement system. In practice, a single instrument can hardly solve both problems simultaneously.

Simultaneous use of multiple instruments requires an overall strategy that recognizes the relative advantages and disadvantages of the instruments. Otherwise, if the instruments are planned and used in isolation from each others, there is a risk that the effects of innovation policies cancel out each others. For example, firms committing open source licensing and other weaker forms of intellectual property should all other things equal be prioritized when granting $R \& D$ subsidies. If not, the combined policy of intellectual property and $R \& D$ subsidies wipes out some of the theoretical advantages of the policy tools making it more likely that combined policy does not increase welfare. As another default rule, prizes should be awarded only if the prize winning innovator commits to waive intellectual property and put the innovation in public domain. Otherwise the major welfare advantage of prizes is eliminated. To some extent similar considerations apply to public production ${ }^{7}$.

Another danger in the design of public innovation policies in the absence of clear overall plan is that the

\footnotetext{
${ }^{7}$ Obviously there are circumstances where public funding of innovative activities must be combined with intellectual property incentives. Such a combined policy will create strong incentives to invest in R\&D and provide external private sector funding, hence eliciting innovations that would not otherwise be created (Maurer and Scotchmer 2004). But these exceptional circumstances are easier to isolate when the correct default rule is applied.
} 
outcomes tend to arise as part of political equilibrium, reflecting the political influence of various interest groups rather than social welfare gains. A particular concern is that a limited number of influential property right holders may more easily organize themselves into an influential lobby group than dispersed users and consumers. Most clearly this has been the case when the duration of intellectual property protection has retrospectively been lengthened in several jurisdictions over the past twenty years after intensive lobbying, e.g., such as the Copyright Term Extension Act of 1998 in the U.S., and Directive 2011/77/EU). To the extent that an increase in the duration of intellectual property apply to existing works it has no economic justification as it merely transfers wealth from users and consumers to property right holders, having no impact on incentives but increasing the dead-weight loss. For example, some commentators (see e.g. Lessig 2004) suggest that the retrospective increase of copyright duration embodied to the Copyright Term Extension Act of 1998 was heavily influenced by the lobby of Walt Disney corporation aimed at prolonging the period of exclusive ownership of Disney characters.

The discussion so far has been restricted to the existing instruments. Academics have however put forward many novel instruments that should in theory improve upon existing ones ${ }^{8}$. In a much discussed contribution, Kremer (1998) comes up with a fairly simple public patent-buy out mechanism which would combine the advantages of intellectual property and prizes.

Ultimately the efficiency of existing and novel instruments is tested in practice. There is no better way to explore the benefits and costs of various innovative policies in practice than running a carefully designed randomized policy experiments ${ }^{9}$.

\section{INNOVATION POLICIES IN FINLAND}

While all major forms of innovation policy have been employed in Finland thorough the history, the current innovation policy is based on intellectual property, subsidies, and public production (Georghiou et al. 2003; Veugelers et al. 2009). As will be discussed in the next subsections, neither R\&D tax reliefs nor prizes are used systematically as an innovation policy tool.

\footnotetext{
${ }^{8}$ Designing a truly optimal innovation policy mechanism poses a daunting task for theoretical research. Advances to this direction are made by Gallini and Scotchmer (2002) and Hopenhayn, Llobet, and Mitchell (2006).

${ }^{9}$ Randomized experiments have become an important part of the development policy design (Duflo and Kremer 2005), and they are likely to be incorporated in the innovation policy design in future.
}

An important aspect of the Finnish innovation-policy environment is that Finland is a small open economy. This means that the Finnish innovation-policy makers should emphasize the ex ante problem of providing incentives to innovate and the ex post problem of creating externalities only to the extent it matters the Finnish economy. In particular, the foreign incentives to innovate and consumer surplus should be ignored. As pointed out by Scotchmer (2004a) and Toivanen (2008), the small open economy aspect modifies the standard predictions of economics of innovation. Consider for example the combined policy of awarding R\&D subsidies together with intellectual property. While the standard theory suggests that the firms waiving intellectual property should be prioritized when granting R\&D subsidies, in a small open economy the argument does not apply to exporting firms. Similarly, even if strong intellectual property rights were conducive for innovation globally, there would be less need to base the Finnish innovation system on strong intellectual property, since this would harm domestic consumers without increasing the exporters' incentives to innovate ${ }^{10}$.

\subsection{Current Issues in the Finnish Innovation Policy: Tax Reliefs and National Intellectual Property Rights Strategy}

There are on-going reform processes on the Finnish innovation policy, of which two are touched upon here. First, following the trend in other OECD countries the Finnish Government has agreed to introduce tax incentives for $R \& D$ investments and their funding by individual investors (business angels), in addition to the existing R\&D subsidy schemes. While there is a plenty of research on R\&D subsides on the one hand (see Section 3.2.) and R\&D tax reliefs on the other hand (see Section 3.3.), and some comparisons of these instruments (see, e.g., Møen 2007), there is little research on the design of a system where $R \& D$ tax reliefs and subsidies are used simultaneously (for the nascent literature, see Busom et al. 2012). There is at least a good theoretic reason for the absence of such research: subsidies, if set optimally, are a superior technology policy tool. Moreover, if a R\&D tax credit scheme is introduced on the top of an optimal subsidy policy, its only effect is that subsidy rates will be

\footnotetext{
${ }^{10}$ Again this is merely a default rule from which deviations are plausible in some circumstances. For example, weak domestic intellectual property system would generally harm the non-exporters' incentives to innovate, and weak trade secret and other intellectual property laws facilitating technological spillovers abroad could also jeopardize the exporter's incentives to innovate.
} 
adjusted accordingly ${ }^{11}$. As a result, there will be no impact on the R\&D investments or social welfare.

But, of course, in practice the subsidy rates are not set optimally nor are all R\&D projects subsidized (either because subsidies were not applied for in the first place or because applications were rejected). Thus one potential effect of the introduction of R\&D tax credits to complement an existing subsidy policy is that most firms taking advantage of tax reliefs will increase their R\&D spending, but the increase is larger in the case of the projects that are not subsidized. It is also clear that tax credits would more likely be welfare-improving if they could be made industry (if not project) specific, favoring industries with higher externalities. The tax credit scheme should also try to take into account the existing subsidy policy.

Another important issue in Finland is a national intellectual property rights strategy. The Finnish Government has frequently reformed intellectual property legislation and policies over the past decade but this has been done in an ad hoc basis. As already argued, such policy making is particularly exposed to lobbying, and unforeseen, counterproductive effects arising from the interaction with other policies. Hence the Finnish Government Resolution for a National Intellectual Property Rights Strategy (26 March, 2009) is a welcome attempt to provide a coherent framework for guiding policymaking. However, it appears that the experts drafting the strategy mainly represent the various industry interest groups. As against this background, the strategy is fairly balanced but, nonetheless, it is not surprising that intellectual property rights are not viewed as a key means to promote domestic economic growth. For example, the international dimension of the strategy does not appropriately recognize the aforementioned open economy aspect, nor does it consider how to ensure the Finnish consumers' and firms' ability to adopt innovations made abroad. In line with the predictions of political economy, the strategy pays relatively little attention to consumer or user rights.

It is also evident that the strategy draws more from the industry practices and intuitive ideas rather than established research results. In some cases research results support the strategy recommendations, but in

\footnotetext{
${ }^{11} \mathrm{~A}$ back-of-the-envelope calculation suggests that if corporate tax rate is $30 \%$ and R\&D investments enable a deduction of $20 \%$ against corporate taxes, the optimal subsidy percent should be reduced by $8.5\left(0.2^{*} 0.3 / 0.7\right)$ percentage points.
}

some cases they do not. Consider, for example, the aim of making the Finnish Market Court as the centralized special court hearing all intellectual property cases. Such centralization has intuitive appeal, enabling specialization and thereby raising the standards of arguments presented in the court. However, such centralization, unless well designed, may have unintended, adverse consequences and potentially slow down the rate of innovation. For example, this may have been a result of the formation of the centralized appeals court (the Court of Appeals for the Federal Circuit) for the patent and trademark cases in the U.S. (Jaffe and Lerner 2004; Bessen and Meurer 2008).

\subsection{Looking Ahead: Prizes in the Finnish Innovation Policy}

Besides tax credits, prizes constitute a notable absence from the array of innovation policies employed in Finland. Finland does award the world's biggest technology prize (the Millenium Technology Prize) but, generally, prizes are neither seen nor used as an innovation policy tool. Moreover, even the Millenium Prize is an example of a blue-sky prize without clear effects on incentives or diffusion of innovations. Instead, there is an argument for including targeted prizes in the innovation policy toolkit, especially in areas where they should work but other innovation policies are at risk of failing. For example, there are numerous diseases that are more prevalent in Finland than elsewhere in the world. Given the small market size, pharmaceutical firms lack the incentive to develop new drugs for such diseases. Many innovation policy instruments such as intellectual property, subsidies and tax incentives perform poorly in such an environment. But since the need for new drugs and therapies is clearly identified, posting a correctly designed prize would be a simple means to complement market incentives.

\section{CONCLUSIONS}

It has been long recognized that innovation is crucial to social welfare but that a competitive market economy may produce an inefficient rate of innovation. As a result, numerous policies have been developed to promote innovative activities. This report reviews commonly used innovation policies and their main rationales, paying particular attention to the Finnish institutional environment.

The report argues that using financial market imperfections creating adverse selection to justify 
public innovation finance policies is challenging: The adverse selection argument may imply that private funding of innovative activities or the activities themselves should be taxed, not subsidized. Moral hazard problems in financial markets provide a more sound justification for public funding of private R\&D. There might also be a room for counter-cyclical innovation finance policies that increase public funding when liquidity in financial markets becomes scarce but and restrict it when private sector funding is cheap to come by.

In contrast, externalities such as technological spillovers and consumer surplus provide a sound rationale for innovation policies. R\&D activities generate large externalities because of the public good aspects of new knowledge, technologies and creative works: it is both difficult and socially wasteful to restrict their use.

All innovation policies encounter the tradeoff of providing ex ante incentives to innovate and diffuse innovations ex post. A single instrument can hardly solve both problems simultaneously, calling for the simultaneous use of multiple instruments. As a result, the use of each instrument should not be designed in isolation from each others but designing their simultaneous use requires an overall economic strategy that recognizes the relative advantages and disadvantages of the instruments. In the Finnish case, such a strategy should also take into account the small open economy aspect, which affects the relative efficiency of the policy instruments in solving the ex ante and ex post problems Otherwise, there is a risk that the effects of innovation policies cancel out each others or that they merely reflect political influence of various interest groups rather than economic efficiency.

The current Finnish innovation policy hinges on intellectual property, direct R\&D subsidies, and public production. Other major forms of innovation policy such as $R \& D$ tax reliefs and prizes are used at best in a very restricted manner, although there is strong political will to introduce tax reliefs in the future, following the trends in other OECD countries. Clearly there would be scope for carefully designed randomized policy experiments of the use of new instruments and the new uses of current instruments.

\section{ACKNOWLEDGEMENT}

I thank two anonymous referees, Ari Hyytinen, Petri Rouvinen, Tanja Tanayama, Otto Toivanen and Pekka
Ylä-Anttila for comments. Funding from ETLA (the Research Institute of the Finnish Economy) and the Seventh Framework Programme of the European Commission is gratefully acknowledged. I also thank the Faculty of Economics, University of Cambridge, for hospitality while working on this study, and the Yrjö Jahnsson Foundation for funding the visit.

\section{REFERENCES}

Aghion, Philippe and Peter Howitt. 2009. The Economics of Growth Cambridge, MA: MIT Press.

Arrow, Kenneth J. 1962. "Economic Welfare and the Allocation of Resources for Invention." Pp. 609-626 in The Rate and Direction of Economic Activities: Economic and Social Factors, edited by R. Nelson. Princeton, NJ: Princeton University Press.

Busom, Isabel, Beatriz Corchuelo, and Ester Martinez Ros. 2012. "Tax Incentives or Subsidies for R\&D." UNU-MERIT Working Paper Series 2012-056.

Bessen, James and Michael J. Meurer. 2008. Patent Failure: How Judges, Bureaucrats and Lawyers Put Innovators at Risk. Princeton, NJ: Princeton University Press.

Boadway, Robin and Michael Keen. 2006. "Financing and Taxing New Firms under Asymmetric Information." FinanzArchiv 62(4): 471-502. http://dx.doi.org/10.1628/001522106X172661

Boldrin, Michele and David Levine. 2008. "Perfectly Competitive Innovation." Journal of Monetary Economics 55(3): 435-453. http://dx.doi.org/10.1016/j.jmoneco.2008.01.008

Chaminade, Christina and Charles Edquist. 2006. "Rationales for Public Policy Intervention from a Systems of Innovation Approach: The Case of VINNOVA." CIRCLE Electronic Working Paper Series No. 2006/04.

Cerulli, Giovanni. 2010. "Modelling and Measuring the Effect of Public Subsidies on Business R\&D: A Critical Review of the Economic Literature." Economic Record 86(274): 421-449. http://dx.doi.org/10.1111/j.1475-4932.2009.00615.x

David, Paul A., Bronwyn H. Hall, and Andrew A. Toole. 2000. "Is Public R\&D a Complement or a Substitute for Private R\&D? A Review of the Econometric Evidence." Research Policy 29(4): 497-529. http://dx.doi.org/10.1016/S0048-7333(99)00087-6

De Meza, David. 2002. "Overlending?" Economic Journal 112(February): F17-F31. http://dx.doi.org/10.1111/1468-0297.00681

De Meza, David and David C. Webb. 1987. "Too Much Investment: A Problem of Asymmetric Information." Quarterly Journal of Economics 102(2): 281-292. http://dx.doi.org/10.2307/1885064

Duflo, Esther and Michael Kremer. 2005. "Use of Randomization in the Evaluation of Development Effectiveness." Pp. 205-232 in Evaluating Development Effectiveness, edited by $\mathrm{G}$. Pitman, O. Feinstein, and G. Ingram. New Brunswick, NJ: Transaction Publishers.

Gallini, Nancy and Suzanne Scotchmer. 2002. "Intellectual Property: When Is It the Best Incentive Mechanism?" Pp. 51-78 in Innovation Policy and the Economy. Vol. 2, edited by A. Jaffe, J. Lerner, and S. Stern. Cambridge, MA: MIT Press.

Garciá-Quevedo, José. 2004. "Do Public Subsidies Complement Business R\&D? A Meta-analysis of the Econometric Evidence." KYKLOS 57(1): 87-102. http://dx.doi.org/10.1111/i.0023-5962.2004.00244.x

Georghiou, L., Smith, K., Toivanen, O. and Ylä-Anttila, P. (2003) Evaluation of the Finnish Innovation Policy Support System. Ministry of Trade and Industry (Finland) Publications 5/2003. 
Green, Jerry R. and Suzanne Scotchmer. 1995. "On the Division of Profit in Sequential Innovation." RAND Journal of Economics 26(1): 20-33. http://dx.doi.org/10.2307/2556033

Hall, Bronwyn H. 2002. "The Financing of Research and Development." Oxford Review of Economic Policy 18(1): 3551.

http://dx.doi.org/10.1093/oxrep/18.1.35

Hall, Bronwyn. H. and John Van Reenen. 2000. "How Effective Are Fiscal Incentives for R\&D? A Review of the Evidence." Research Policy 29(4-5): 449-469. http://dx.doi.org/10.1016/S0048-7333(99)00085-2

Henry, Emeric and Carlos J. Ponce. 2011. "Waiting to Imitate: On the Dynamic Pricing of Knowledge." Journal of Political Economy 119(5): 959-981. http://dx.doi.org/10.1086/662721

Holmström, Bengt and Jean Tirole. 1997. "Financial Intermediation, Loanable Funds, and the Real Sector." Quarterly Journal of Economics 112(3): 663-691. http://dx.doi.org/10.1162/003355397555316

Hopenhayn, Hugo A., Gerard Llobet, and Matthew F. Mitchell. 2006. "Rewarding Sequential Innovators: Prizes, Patents, and Buyouts." Journal of Political Economy 114(6): 1041-1068. http://dx.doi.org/10.1086/510562

Hyytinen, Ari and Mika Pajarinen. 2003. "Small Business Finance in Finland: A Descriptive Study." Pp. 203-204 in Financial Systems and Firm Performance: Theoretical and Empirical Perspectives. ETLA B: 200, edited by A. Hyytinen and M. Pajarinen. Helsinki: Taloustieto.

Jaffe, Adam. B. and Josh Lerner. 2004. Innovations and Its Discontents: How Our Broken Patent System is Endangering Innovation and Progress, and What to Do About It. Princeton, $\mathrm{NJ}$ : Princeton University Press.

Klette, Tor J., Jarle Møen and Zvi Griliches. 2000. "Do Subsidies to Commercial R\&D Reduce Market Failures? Microeconomic Evaluation Studies." Research Policy 29 (4-5): 471-495. http://dx.doi.org/10.1016/S0048-7333(99)00086-4

Kremer, Michael. 1998. "Patent Buyouts: A Mechanism for Encouraging Innovation." Quarterly Journal of Economics 113(4): 1137-1168. http://dx.doi.org/10.1162/003355398555865

Lerner, Josh. 2002. "When Bureaucrats Meet Entrepreneurs: The Design of Effective Public Venture Capital Programmes." Economic Journal 112(February): F73-F84. http://dx.doi.org/10.1111/1468-0297.00684

Lessig, Lawrence. 2004. Free Culture. New York, NY: Penguin Press.

Maurer, Stephen M. and Suzanne Scotchmer. 2004. "Procuring Knowledge." Pp. 1-31 in Intellectual Property and Entrepreneurship: Advances in the Study of Entrepreneurship, Innovation and Growth. Vol. 15, edited by G. Libecap. Amsterdam: JAI Press (Elsevier).

Menell, Peter S. and Suzanne Scotchmer. 2007. "Intellectual Property." Handbook of Law and Economics, edited by M. Polinsky and S. Shavell. Amsterdam: Elsevier. http://dx.doi.org/10.1016/S1574-0730(07)02019-1

Mohnen, Pierre. and Boris Lokshin. 2010. "What Does It Take for an R\&D Tax Incentive Policy to Be Effective?" Pp. 33-58, in Reforming Rules and Regulations, edited by V. Ghosal. Cambridge, MA: MIT Press.
Møen, Jarle. 2007. "Should Finland Introduce an R\&D Tax Credit? Reflections Based on Experience with Norwegian R\&D Policy." ETLA Discussion Papers No. 1097.

Niinimäki, Juha-Pekka and Tuomas Takalo. 2007. "Benchmarking and Comparing Entrepreneurs with Incomplete Information." Finnish Economic Papers 20(2): 91-103.

OECD. 2011. OECD Science, Technology and Industry Scoreboard 2011. OECD Publishing.

Parsons, Mark and Nicholas Phillips. 2007. "An Evaluation of the Federal Tax Credit for Scientific Research and Experimental Development." Department of Finance (Canada), Working Paper 2007-08.

Scotchmer, Suzanne. 2004a. "The Political Economy of Intellectual Property Treaties." Journal of Law, Economics, and Organizations 20(2): 415-437. http://dx.doi.org/10.1093/jleo/ewh040

Scotchmer, Suzanne. 2004b. Innovation and Incentives. Cambridge, MA: MIT Press.

Sobel, Dava. 1995. Longitude: The True Story of a Lone Genius Who Solved the Greatest Scientific Problem of His Time. New York, NY: Walker.

Solow, Robert. 1956. "A Contribution to the Theory of Economic Growth." Quarterly Journal of Economics 70(1): 65-94. http://dx.doi.org/10.2307/1884513

Solow, Robert. 1957. "Technical Change and Aggregate Production Function." Review of Economic and Statistics 39(3): 312-320. http://dx.doi.org/10.2307/1926047

Stiglitz, Joseph E. and Andrew Weiss. 1981. "Credit Rationing in Markets with Imperfect Information." American Economic Review 71(3): 393-410.

Takalo, Tuomas and Tanja Tanayama. 2010. "Adverse Selection and Financing of Innovation: Is There Need for R\&D Subsidies?" Journal of Technology Transfer 35(1): 16-41. http://dx.doi.org/10.1007/s10961-009-9112-8

Takalo, Tuomas, Tanja Tanayama, and Otto Toivanen. 2011. "Estimating the Benefits of Targeted R\&D Subsidies." Forthcoming in Review of Economics and Statistics.

Takalo, Tuomas, Tanja Tanayama, and Otto Toivanen. 2012. "Market Failures and the Additionality Effects of Public Support to Private R\&D: Theory and Empirical Implications." Paper presented at the Annual Meeting of the European Association for Research in Industrial Economics, September 4, Rome, Italy.

Toivanen, Otto. 2008. "National Innovation Policy in an Internationa World - Perspectives from Finland." Pp. 118-122 in Going Global: The Challenges for Knowledge-based Economies, edited by M. Squicciarini and T. Loikkanen. Publications of The Ministry of Employment and the Economy (Finland) 20/2008.

Veugelers, Reinhilde, et al. 2009. Evaluation of the Finnish National Innovation System- Full Report. Helsinki: Taloustieto.

Warda, Jacek. 2006. "Tax Treatment of Business Investments in Intellectual Assets: An International Comparison." OECD Science Technlogy and Indusry Working Papers Number 2006/4.

Zúñica-Vicente, JoséÁngel, César Alonso-Borrego, Francisco J. Forcadell, and José I. Galan. 2012. "Assessing the Effect of Public Subsidies on Firm R\&D Investment: A Survey." Forthcoming in Journal of Economic Surveys.

\section{DOI: http://dx.doi.org/10.6000/1929-7092.2012.01.14}

(c) 2012 Tuomas Takalo; Licensee Lifescience Global.

This is an open access article licensed under the terms of the Creative Commons Attribution Non-Commercial License (http://creativecommons.org/licenses/by-nc/3.0/) which permits unrestricted, non-commercial use, distribution and reproduction in any medium, provided the work is properly cited. 